\title{
Effect of pedogenic iron-oxyhydroxide removal on the metal sorption by soil clay minerals
}

\author{
Péter Sipos ${ }^{1}$ - Viktória Kovács Kis ${ }^{2} \cdot$ Réka Balázs $^{1} \cdot$ Adrienn Tóth $^{3} \cdot$ Tibor Németh $^{1}$
}

Received: 10 November 2020 / Accepted: 5 February 2021 / Published online: 19 February 2021

(C) The Author(s) 2021

\begin{abstract}
Purpose The close association of Fe-oxyhydroxides and clay minerals might influence the sorption properties of these components. We aimed to study the effect of removing the pedogenic Fe-oxyhydroxides on the sorption of $\mathrm{Cd}, \mathrm{Cu}, \mathrm{Pb}$, and $\mathrm{Zn}$ by the clay mineral particles in soils with contrasting $\mathrm{pH}$.

Methods Competitive batch sorption experiments before and after Fe-oxyhydroxide extraction in soils were carried out together with the direct analysis of the metal sorption on individual particles of ferrihydrite, smectite, and illite/smectite by TEM.

Results Ferrihydrite was a more effective metal sorbent than clay minerals, although its removal resulted in decreased sorption only for $\mathrm{Cd}, \mathrm{Cu}$, and $\mathrm{Zn}$. Ferrhydrite coating blocked metals' access for certain sorption sites on clay surfaces, which were only accessible for $\mathrm{Pb}$ as the most efficient competitor after removing the coating. This observation was the most remarkable for the smectite particles in the alkaline soil. Mineral surfaces sorbed higher $\mathrm{Cu}$ than $\mathrm{Pb}$ concentrations and higher $\mathrm{Zn}$ than $\mathrm{Cd}$ concentrations despite the former metals' lower bulk sorption. Thus, organic surfaces and precipitation contributed to $\mathrm{Pb}$ and $\mathrm{Cd}$ 's retention to a greater extent than for $\mathrm{Cu}$ and $\mathrm{Zn}$. The structural $\mathrm{Fe}$ of smectite also promoted the metal sorption in both soils.

Conclusion Removal of iron-oxyhydroxide coatings from the soil affects metal sorption selectively. Direct study of metal sorption on individual soil particles enables us to gain a more in-depth insight into soil minerals' role in this process.
\end{abstract}

Keywords Ferrihydrite coating, $\cdot$ Smectite, $\cdot$ Metal sorption, $\cdot$ DCB extraction, $\cdot$ TEM

\section{Introduction}

The risk of metals pose due to their toxic potential depends substantially on their sorption equilibria and dynamics in soils. A heterogeneous soil system consists of both organic and inorganic constituents with different affinities for metals. Soil organic matter, clay minerals, and Fe-oxyhydroxides are primarily involved in metals' sorption (Shaheen et al. 2013). The

Responsible editor: Dong-Mei Zhou

Péter Sipos

sipos@geochem.hu; sipos.peter@csfk.org

1 Institute for Geological and Geochemical Research, Research Centre for Astronomy and Earth Sciences, Eötvös Loránd Research Network, Budapest, Hungary

2 Institute of Technical Physics and Materials Science, Centre for Energy Research, Eötvös Loránd Research Network,

Budapest, Hungary

3 Geographical Institute, Research Centre for Astronomy and Earth Sciences, Eötvös Loránd Research Network, Budapest, Hungary heterogeneous nature of these components and their particle interactions are well-known phenomena in soils (Zachara et al. 1992). Metal sorption on a given soil component is not only influenced by the co-existence of other phases (Violante and Pigna 2002), but they may change the surface properties for each other, and they can form ternary complexes (Rafaey et al. 2017) or particle associations (Sipos et al. 2018). Hydrous Fe oxides are often present as partial coatings on phyllosilicates in soils rather than discrete, well-crystallized minerals (Wu et al. 2017; Gomez-Gonzalez et al. 2018).

Moreover, clay minerals have a significant role in the formation and stability of Fe-bearing solid phases during redox cycles in soils (Van Groeningen et al. 2020). Several studies showed the importance of these surface coatings in controlling metal distribution in soils and sediments (Zachara et al. 1995; Uygur and Rimmer 2000). According to Xu and Axe (2005), as the nano-sized oxyhydroxide coatings increase the surface area, introduce small pores, and change the host particle's surface charge distribution, so the coated system may exhibit a larger affinity for metals. Saha et al. (2002) found that the close association of oxyhydroxides and clay minerals might significantly enhance these components' adsorption 
capacities. These properties allow the Fe oxyhydroxides to exert chemical activity far out of proportion to their concentration.

The direct study of metals sorption by soil components demonstrated that the association of iron and clay minerals plays a unique role in retaining metals (Sipos et al. 2009). In some instances, these associations' contributions may be even greater than the summation of the effects of the individual components themselves (Cerqueira et al. 2015). Sipos et al. (2018) found that Fe concentrations of the individual soil mineral particles often positively correlate with the sorbed metal concentrations. This correlation was related to the increasing contribution of $\mathrm{Fe}$ oxyhydroxides within the particle associations in alkaline soils and the increasing Fe concentration of clay mineral particles in acidic ones (Sipos et al. 2019). Laboratory experiments studying the sorption characteristics of clay minerals coated by Feoxyhydroxides also revealed the importance of such coatings in metal retention. Borgnino et al. (2009) observed that the coating of montmorillonite by ferrihydrite increased the specific surface area and, as a result of this, the clay mineral phase's sorption capacity. Additionally, Wu et al. (2009) found that Femontmorillonite adsorbed higher amounts of $\mathrm{Cd}$ than Ca-montmorillonite, which was related to the larger interlayer spacing of the former. Contrarily, a coating may also decrease the soil minerals' metal sorption capacity by blocking the specific binding sites of the coated particles, as was found by Refaey et al. (2014) after coating $\mathrm{Fe}$-oxyhydroxides and clay minerals with organic matter. The above results were obtained on model colloid assemblages prepared in the laboratory, and still, there are no data through direct observations of these phases within soils.

Due to the intimate particle associations of minerals in the soil, it is experimentally challenging to separate the clay minerals' role as metal sorbents in soils quantitatively. To date, several techniques and their combination have been used to quantify the contribution of different sorbent phases to metal sorption in soils (Malandrino et al. 2006; Covelo et al. 2008; Kopittke et al. 2017; Zhao et al. 2018). They had often led to contradictory results when comparing the sorption properties of soils before and after the extraction of Fe-oxyhydroxides. Some studies (Elliot et al. 1988; Wu et al. 1999; Li et al. 2015) found the increase of metal sorption after Fe-oxyhydroxide removal, which could be related to the increased electrostatic attraction between cationic elements and the surface of clay particles after the removal of the coating. Others (Cavallaro and Mcbride 1984; Silveira et al. 2002) found a considerable reduction in the sorption of metals after Fe-oxyhydroxide extraction, which indicated the primary role of the removed phases in metal sorption. The lack of a consistent response to Fe-oxyhydroxide removal reflects the variation of soil mineralogy, the form in which these phases occur (coatings vs. discrete mineral entities), the nature, location, and distribution of metal adsorption sites, and differences in metal sorption characteristics (Wu et al. 1999; Agbenin and Olojo 2004).
Thus, much of the current knowledge on the role of $\mathrm{Fe}$ oxyhydroxides, clay minerals, and their assemblages in metal sorption by soils is still based on the extrapolation of sorption data derived from bulk soils or single soil components. That is why the importance of these components as sorbents in the soil is described still not well. This study has combined several approaches to investigate metals' sorption in soil mineral particles, like Fe-oxyhydroxides and clay minerals. We used batch sorption experiments on bulk soils, direct analysis of metals sorption on individual soil mineral particles, and selective extraction of Fe-oxyhydroxides from the soil together to study mineral surfaces' role in sorption of $\mathrm{Cd}, \mathrm{Cu} \mathrm{Pb}$, and $\mathrm{Zn}$. We aimed to investigate the effect of removing the ferrihydrite on the sorption of metals by smectite and illite/smectite particles in mineral soils with contrasting $\mathrm{pH}$. The role of soil organic matter (SOM) in this process will not be evaluated in detail. However, it can be closely associated with the poorly crystalline soil mineral phases, affecting their metal sorption properties. For example, according to Mikutta et al. (2006), mineral dissolution released, on average, $73 \%$ of the stable organic carbon in forest soils. However, this portion of SOM can be extracted only by strong soil acidification, resulting in changes in the soil mineralogy (Swift 1996). That is why we used mineral soils with similarly low organic matter content in this study to minimize the differences in metal sorption due to organic coatings on the studied mineral surfaces.

\section{Materials and methods}

\subsection{Soils and sample preparation}

We studied two soil samples showing similar physicochemical and clay mineralogical characteristics except for their $\mathrm{pH}$. The sample with acidic $\mathrm{pH}$ was collected from a Luvisol $\mathrm{B}_{\mathrm{t}}$ horizon (sample LB), whereas the one with alkaline $\mathrm{pH}$ from a Pheaozem $\mathrm{C}_{\mathrm{k}}$ horizon (sample PC). Their other properties, like total organic carbon content (TOC), BET-surface area (BET), cation exchange capacity (CEC), iron, and clay content, showed very similar values (Table 1). Additionally, their clay mineralogy can be characterized by the dominant presence of smectite and illite-smectite mixed layer species, as shown by the X-ray diffractometric analyses (Figure S1).

For the samples' physicochemical characterization and the metal sorption experiments, the samples were air-dried, sieved through a 2-mm sieve, and finally crushed gently in an agate mortar. The clay fraction of the samples were separated by sedimentation in aqueous suspension. After Harris and White (2008), several diagnostic treatments were carried out on the clay fractions to identify the clay mineral species by XRD.

Iron-oxyhydroxides were extracted from the soils using the modified dithionite-citrate-bicarbonate $(\mathrm{DCB})$ procedure by 
Table 1 Major physicochemical properties of the studied samples. $L B$ Luvisol B horizon, $P C$ Phaeozem C horizon

\begin{tabular}{lllllllll}
\hline & $\begin{array}{l}\mathrm{pH} \\
\left(\mathrm{CaCl}_{2}\right)\end{array}$ & $\begin{array}{l}\mathrm{TOC} \\
(\mathrm{g} / \mathrm{kg})\end{array}$ & $\begin{array}{l}\mathrm{BET} \\
\left(\mathrm{m}^{2} / \mathrm{kg}\right)\end{array}$ & $\begin{array}{l}\mathrm{CEC} \\
(\mathrm{mmol} / \mathrm{kg})\end{array}$ & $\begin{array}{l}\mathrm{Fe} \\
(\mathrm{g} / \mathrm{kg})\end{array}$ & $\begin{array}{l}\mathrm{Fe}_{\mathrm{DCB}} \\
(\mathrm{g} / \mathrm{kg})\end{array}$ & $\begin{array}{l}\mathrm{Clay}^{\mathrm{CaCO}} \\
(\%)\end{array}$ \\
\hline Sample LB & $4.28 \pm 0.01$ & $0.54 \pm 0.07$ & $33 \pm 1.1$ & $14.0 \pm 0.46$ & $40.3 \pm 2.0$ & $19.7 \pm 1.0$ & $19.2 \pm 1.7$ \\
Sample PC & $7.93 \pm 0.01$ & $0.34 \pm 0.09$ & $29 \pm 0.5$ & $12.4 \pm 0.22$ & $44.5 \pm 1.4$ & $37.2 \pm 3.0$ & $18.1 \pm 2.1$ & $22.8 \pm 0.5$ \\
\hline
\end{tabular}

Jackson et al. (1986). The extraction temperature was lowered from the suggested $75-80$ to $50^{\circ} \mathrm{C}$, as we observed partial dissolution of both clay mineral and calcite particles by transmission electron microscopy (TEM) after the extraction at the former temperature (Figure S2). Several other studies reported such dissolution (Rennert 2019), and it is related to the fact that citrate may form complexes with $\mathrm{Ca}^{2+}$ and $\mathrm{Al}^{3+}$. It is even used to extract both carbonates and silicates from soils (Shang and Zelazny 2008). We have not observed the particle corrosion in the studied samples using the DCB procedure at $50^{\circ} \mathrm{C}$. Additionally, we have found no significant difference between the extracted iron at the two temperatures in both samples. After the extractions, soil samples were washed three times with distilled water, and after that, they were equilibrated with $0.01 \mathrm{M} \mathrm{Ca}\left(\mathrm{NO}_{3}\right)_{2}$ solution at $\mathrm{pH} 5.5$ for $1 \mathrm{~h}$ to remove the residuals of chemicals.

Competitive batch sorption experiments were carried out on the soil samples before and after the iron-oxyhydroxide extractions in duplicates. The initial $\mathrm{Cd}, \mathrm{Cu}, \mathrm{Pb}$, and $\mathrm{Zn}$ (added in the form of nitrate) concentrations were set to $0.1-$ $10 \mathrm{mmol} / \mathrm{L}$ in a $0.01 \mathrm{M} \mathrm{Ca}\left(\mathrm{NO}_{3}\right)_{2}$ background electrolyte solution with an initial $\mathrm{pH}$ of 5.5. Soil samples of $1 \mathrm{~g}$ were equilibrated with $30 \mathrm{~mL}$ of solutions by shaking for $24 \mathrm{~h}$ at room temperature. Metal concentrations and $\mathrm{pH}$ of the solutions were analyzed after centrifugation of the suspension at $4000 \mathrm{rpm}$ for $20 \mathrm{~min}$ and filtering the supernatant.

TEM analyses were carried out on the initial samples before and after iron oxide extractions and also on samples equilibrated with the solutions containing the highest initial metal concentrations. For these analyses, the washed, Ca-saturated, and air-dried samples were slightly grounded under ethanol to have a suspension. A drop of the resulting suspension was deposited onto a pure carbon-coated gold TEM grid (Ted Pella).

\subsection{Analytical methods}

Soil $\mathrm{pH}$ was analyzed in $0.1 \mathrm{M} \mathrm{CaCl}_{2}$ solution with a soil to solution ratio of $1: 2.5$. The TOC content was studied with a TOC analyzer (Tekmar-Dohrmann Apollo 9000N), the BETsurface area using gas sorption with $\mathrm{N}_{2}$ gas (Quantochrome Autosorb-1-MPV), and the particle size distribution with the laser diffraction method (Fritsch Analysette Microtech A22). The cation exchange capacity of the soils was studied after the
ISO 23470:007 (2007) method with $\left[\mathrm{Co}\left(\mathrm{NH}_{3}\right)_{6}\right] \mathrm{Cl}_{3}$ solution, and atomic absorption spectrometry (AAS) was used to analyze the Co concentrations in the solutions (Perkin Elmer AAnalyst 300). The carbonate content was determined with the Scheibler calcimeter method. Clay mineralogical analysis was carried out by powder X-ray diffraction (Rigaku Miniflex $600)$. The concentration of Fe extracted by the DCB procedure was analyzed by the AAS method.

Metal concentrations in the equilibrium solutions of the sorption experiments were studied by AAS. The Langmuir and Freundlich equations were used to describe the metals' adsorption from the solution to the solids (Tran et al. 2017). The equations are given in the supplementary material. Langmuir maximum saturated monolayer capacity $\left(\mathrm{Q}_{\mathrm{m}}-\right.$ $\mathrm{mmol} / \mathrm{kg})$, Langmuir separation factor $\left(\mathrm{R}_{\mathrm{L}}-\right.$ dimensionless $)$, as well as Freundlich constant $\left(\mathrm{K}_{\mathrm{F}}-\mathrm{mmol} / \mathrm{kg}\right)$ were used to evaluate the sorption characteristics of the studied samples. Isotherm model parameters were obtained using non-linear regression analysis. The coefficient of determination $\left(R^{2}\right)$ was used to assess isotherms' applicability to the experimental data.

TEM analyses were carried out using an FEI-Themis 200 G3 microscope for the soil particles' mineralogical characterization. The analyses were carried out at $200 \mathrm{keV}$ with a CS corrected objective lens (FEG, point resolution is around $0.09 \mathrm{~nm}$ in HREM mode) equipped with an FEI Super-X EDS detection system. The high-resolution TEM images were analyzed using Velox (FEI) software. The chemical analysis of the individual soil mineral particles was carried out using a Philips CM20 microscope equipped with a Noran energy dispersive spectrometer (EDS). The instrument was operated at $200 \mathrm{kV}$ with a $\mathrm{LaB}_{6}$ filament. For chemical analyses, a 5-nm beam parameter and counting times of $100 \mathrm{~s}$ were used. The chemical composition was calculated based on $100 \mathrm{~nm}$ sample thickness and $2.5 \mathrm{~g} / \mathrm{cm}^{3}$ density for the silicate particles. In contrast, for large Fe-oxyhydroxide aggregates, the density and thickness were set up to $4.5 \mathrm{~g} / \mathrm{cm}^{3}$ and $500 \mathrm{~nm}$, respectively. Joint evaluation of the diffraction pattern and chemical composition of the particles were used for their identification. Metal sorption capacity of the individual soil mineral particles was studied by the direct analysis of metals' concentration on the given particle by point analyses using EDS. Between 14 and 42 particles was studied by point chemical analysis within the studied particle type groups. 


\subsection{Statistical analyses}

Pearson correlation coefficients between the chemical composition of the studied particles and their sorbed metal concentrations were calculated. Additionally, cluster analysis was carried out on the sorption data to compare the metals' sorption behavior among the studied soil samples and particle types. The following calculations were carried out to show if the sorbed metal concentrations on the different particle types are significantly different. The skewness and kurtosis values between -1 and 1 were verified to provide the assumption of normality when the D'Agostino-Pearson test was significant. Homogeneity of variances was tested through Levene's test and proved for almost all cases. For data sets with normal distribution, the $t$-test was used when two groups were compared, and one-way analysis of variance test was used when more than two groups were compared. In the latter case, the Tukey test was used as a post-hoc analysis. For data sets without normal distribution, the Mann-Whitney test and Kruskall-Wallis test were used to compare two and more groups, respectively. In the latter case, the Mann-Whitney test was used as a post hoc analysis. The significance level of each test was set to $\alpha=0.05$. The statistical analyses were carried out using the StatistiXL add-in of the MS Excel 2016 software.

\section{Results}

\subsection{Physico-chemical and mineralogical characteristics of the studied soils}

The studied samples were collected from mineral horizons, so their organic carbon content is equally low (Table 1). Both of them can be characterized by medium surface area, cation exchange capacity, and clay content. Although their total iron content is also similar, the dithionite-extractable iron content is almost twice as much in the sample PC as in the sample LB. The two samples show high contrast in their $\mathrm{pH}$ : the sample LB is strongly acidic, whereas the sample PC is moderately alkaline. The higher $\mathrm{pH}$ of the sample $\mathrm{PC}$ can be related to its large calcite content. The presence of smectite, illite, and their mixed layer species characterize the samples' clay mineralogy, as shown by XRD analyses. Smectite dominates in the sample PC, whereas rather illite/smectite in the sample LB. Iron-oxyhydroxide minerals could not be detected in the samples by XRD analyses suggesting the presence of such phases of low crystallinity. No mineralogical change could be observed in the samples after the DCB extraction.

The TEM analyses also showed that smectite, illite, and illite-smectite mixed-layer phases are the characteristic clay minerals in the soils. The high-resolution TEM (HRTEM) and its Fourier transform indicated a more ordered structure for the clay particles in the sample LB, suggesting the prevalence of illite/smectite mixed-layer components there (Fig. 1). In the sample PC, however, the diffuse rings on the Fourier transform indicated a rather turbostratic structure of the clay particles showing the dominance of smectites (Fig. 2). On the bright field images, high-contrast particles were commonly observed in both samples. HRTEM images revealed that these particles are randomly oriented, and they have a poorly ordered structure characterized by a dominant ca. 2.5-2.6 $\AA$ lattice spacing. The size of these particles was typically below $20 \mathrm{~nm}$. According to the EDS analysis, they were mostly iron oxyhydroxides with stoichiometry approximating a 1:2 cation-to-oxygen ratio and with phosphorus as a typical minor component. These poorly ordered iron-rich nanoparticles could be best described as ferrihydrite. The ferrihydrite particles mostly formed coatings as heterogeneously distributed flakes on the surface of larger clay mineral lamellae. They also appeared as very large (up to $500 \mathrm{~nm}$ ) aggregates occasionally. Both the iron oxyhydroxide and the clay mineral particles were loosely associated with calcite particles in the sample PC. After the DCB extraction, bright field images indicated clay mineral surfaces free of high contrast nanoparticles in both samples. Thus, the DCB extraction effectively removed the iron-oxyhydroxide particles, although some survived in the sample PC. Simultaneously, the clay particles' integrity was preserved, i.e., no corrosion was observed after the extraction. Clay minerals often proved high iron content, primarily in the sample PC. Iron was located in the smectite crystal structure, which was also supported by the fact that phosphorus could not be detected together with $\mathrm{Fe}$.

\subsection{Metal sorption on the bulk soils before and after the Fe-oxyhydroxide removal}

The results of the sorption experiments on the bulk soils are summarized in Table 2. The sorption curves of the metals in the sample LB belonged to the Langmuir-type (class "L"), whereas those in the sample PC belong to the high-affinity type (class "H") (Figure S3). Sorption curves suggested saturation only in some cases $\left(\mathrm{Cd}\right.$ in the sample $\mathrm{LB}_{\mathrm{DCB}}$ and the sample $\mathrm{PC}, \mathrm{Pb}$ in the sample $\mathrm{LB}$, and $\mathrm{Zn}$ in the sample $\mathrm{PC}$ and the sample $\left.\mathrm{PC}_{\mathrm{DCB}}\right)$. Furthermore, $\mathrm{Pb}$ exhibited an $\mathrm{H}-\mathrm{C}$ combined curve in the sample PC before and after the DCB extraction. This curve showed almost linearly increasing sorbed metal amounts with the increasing adsorbate concentration at higher initial concentrations. Fitting the measured metal sorption data to the Langmuir and Freundlich equations revealed a slightly better fit by the Langmuir equation for $\mathrm{Cd}$ and by the Freundlich equation for all other metals as indicated by the regression coefficients. Although there were small discrepancies in this observation, they did not show any systematic behavior among metals or samples. The regression coefficients of both equations were still very high in each case. 

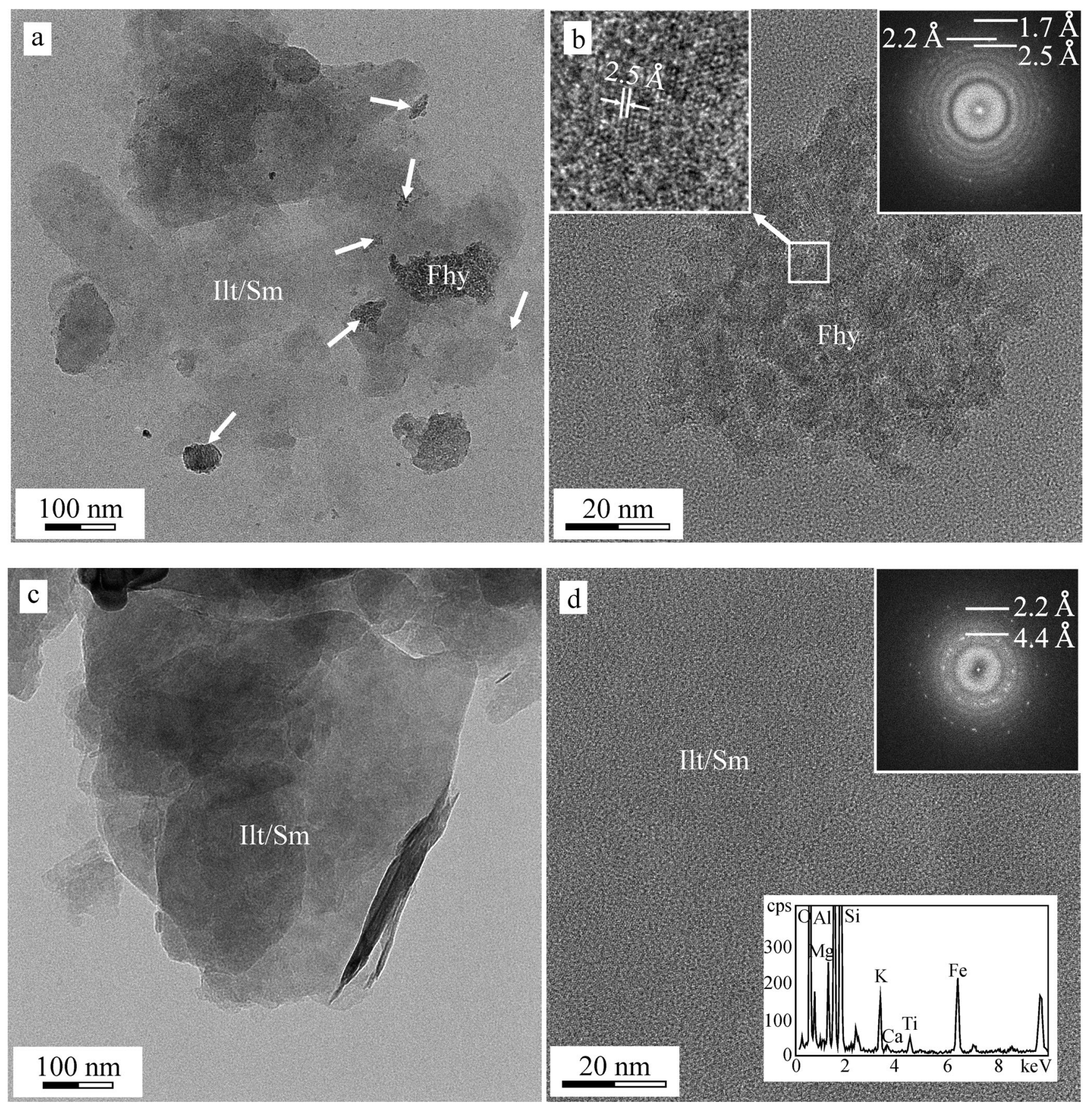

Fig. 1 Characteristics of soil nanoparticles before and after the DCB extraction in the sample LB. a Bright-field images of ferrihydrite-clay mineral associations before the extraction showing ferrihydrite particles (indicated by arrows) distributed around and on the surface of large illite/ smectite lamellae. b The high-resolution TEM image and its Fourier transform show randomly oriented ferrihydrite nanoparticles (Fhy) with a poorly oriented structure, dominated by $2.5 \AA$ lattice spacing. c Bright-

Both the Freundlich exponent and the Langmuir separation factor were lower than 1.0 in each case.

The sorption capacities of the bulk samples were compared using three parameters: sorbed metal concentrations by the samples equilibrated with the initial solution of $10 \mathrm{mmol} / \mathrm{L}$ metal concentrations $\left(\mathrm{M}_{10}\right)$, Langmuir maximum saturated

field images of the illite/smectite (Ilt/Sm) surface after the DCB extraction show the lack of ferrihydrite particles with high contrast. d The highresolution TEM and its Fourier transform indicate a more ordered clay structure of illite/smectite mixed-layer species with considerable $\mathrm{Fe}$ content (as shown by EDS analysis). The illite/smectite particles may contain significant $\mathrm{Fe}$ concentrations even after the DCB extraction showing structural $\mathrm{Fe}$ in the smectite component (see EDS spectrum).

monolayer sorption $\left(\mathrm{Q}_{\mathrm{m}}\right)$, and the Freundlich constant related to sorption capacity $\left(\mathrm{K}_{\mathrm{F}}\right)$. Although $\mathrm{M}_{10}$ is not characteristic for the whole range of the sorption curve, this value was measured directly. Additionally, samples equilibrated with the highest initial metal concentration solutions were used for the TEM-EDS analyses. Both calculated parameters showed 

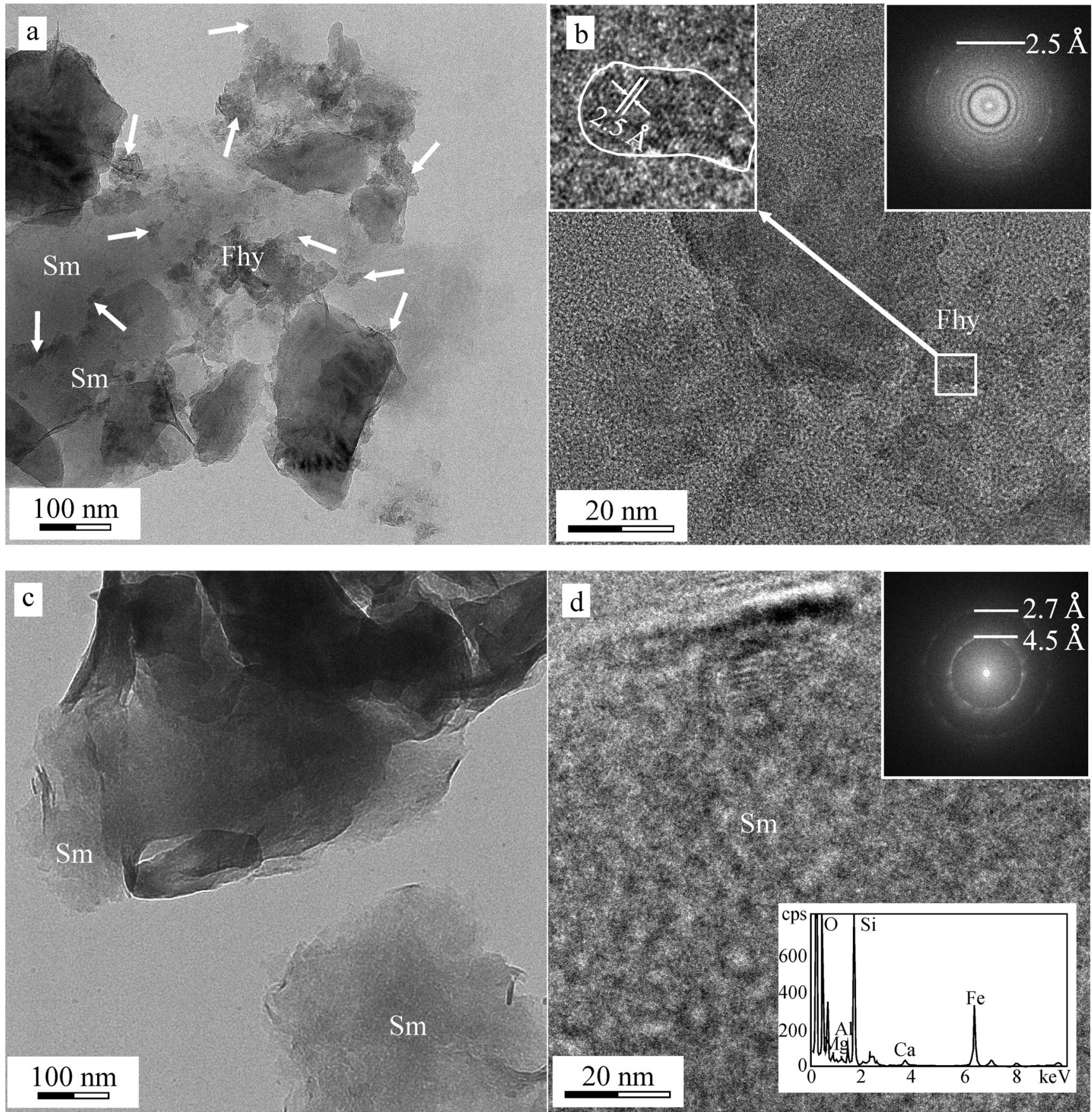

Fig. 2 Characteristics of soil nanoparticles before and after the DCB extraction in the sample PC. a Bright-field images of ferrihydrite-clay mineral associations before the extraction showing ferrihydrite particles (indicated by arrows) distributed around and on the surface of large smectite lamellae. b The high-resolution TEM image and its Fourier transform show randomly oriented nanoparticles of ferrihydrite (Fhy)

a strong positive correlation with the measured one $(r>0.92)$. The values of $\mathrm{M}_{10}$ and $\mathrm{Q}_{\mathrm{m}}$ exhibited very similar values for sorption curves showing saturation, whereas $Q_{m}$ values were 2-4-times higher than $\mathrm{M}_{10}$ values for the $\mathrm{H}-\mathrm{C}$ type curves of $\mathrm{Pb}$. The highest sorption was found for $\mathrm{Pb}$, followed by $\mathrm{Cu}$, although this latter metal showed slightly lower $\mathrm{Q}_{\mathrm{m}}$ values

with a poorly ordered structure, dominated by $2.5 \AA$ lattice spacing. c Bright-field images of the smectite (Sm) surface after the DCB extraction show the lack of ferrihydrite particles with high contrast. d The highresolution TEM and its Fourier transform indicate a typical turbostratic structure of smectite with high Fe content (as shown by EDS analysis)

than $\mathrm{Cd}$ in the sample LB. Among the metals with low sorption, Cd exhibited slightly higher sorption than $\mathrm{Zn}$. However, a somewhat larger amount of $\mathrm{Zn}$ than that of $\mathrm{Cd}$ was sorbed on the sample $\mathrm{LB}_{\mathrm{DCB}}$. The sample $\mathrm{PC}$ sorbed higher metal amounts than the sample LB in each case. The DCB extraction increased the sorption of $\mathrm{Pb}$, whereas it decreased that of $\mathrm{Cd}$, 
Table 2 Summary of the sorption curve evaluation. Curve types were classified after Giles and Smith (1974). $\mathrm{M}_{10}=$ sorbed metal concentration in the samples equilibrated with the solution containing $10 \mathrm{mmol} / \mathrm{L}$ initial metal concentrations; $Q_{m}$ Langmuir maximum saturated monolayer capacity; $b$ Langmuir constant related to the affinity between adsorbent and adsorbate; $R_{L}$ Langmuir separation factor; $K_{F}$ Freundlich constant related to sorption capacity; $n$ Freundlich exponent. Relating equations are given in the supplementary material

\begin{tabular}{|c|c|c|c|c|c|c|c|c|c|}
\hline \multirow[b]{2}{*}{ Sample } & \multirow[b]{2}{*}{ Curve type } & \multirow[b]{2}{*}{$\begin{array}{l}\mathrm{M}_{10} \\
(\mathrm{mmol} / \mathrm{kg})\end{array}$} & \multicolumn{4}{|l|}{ Langmuir } & \multicolumn{3}{|l|}{ Freundlich } \\
\hline & & & $\begin{array}{l}Q_{m} \\
(\mathrm{mmol} / \mathrm{kg})\end{array}$ & $\begin{array}{l}b \\
(\mathrm{~L} / \mathrm{mmol})\end{array}$ & $R^{2}$ & $\mathrm{R}_{\mathrm{L}}$ range & $\begin{array}{l}\mathrm{K}_{\mathrm{F}} \\
(\mathrm{mmol} / \mathrm{kg})\end{array}$ & $n$ & $R^{2}$ \\
\hline \multicolumn{10}{|c|}{ Cadmium } \\
\hline LB & L1 & 12.69 & 16.98 & 0.29 & 0.99 & $0.97-0.27$ & 3.84 & 0.55 & 0.99 \\
\hline $\mathrm{LB}_{\mathrm{DCB}}$ & $\mathrm{L} 2$ & 4.23 & 4.33 & 2.37 & 0.98 & $0.82-0.04$ & 2.53 & 0.27 & 0.92 \\
\hline $\mathrm{PC}$ & $\mathrm{H} 2$ & 21.54 & 22.23 & 142.16 & 0.99 & $0.07-0.001$ & 20.29 & 0.16 & 0.78 \\
\hline $\mathrm{PC}_{\mathrm{DCB}}$ & $\mathrm{H} 1$ & 11.40 & 9.26 & $\begin{array}{l}84.56 \\
\text { Copper }\end{array}$ & 0.71 & $0.11-0.001$ & 7.77 & 0.14 & 0.89 \\
\hline LB & L1 & 13.77 & 15.25 & 0.84 & 0.99 & $0.93-0.11$ & 6.26 & 0.39 & 0.98 \\
\hline $\mathrm{LB}_{\mathrm{DCB}}$ & L1 & 12.75 & 12.54 & 5.21 & 0.99 & $0.66-0.02$ & 8.50 & 0.24 & 0.87 \\
\hline $\mathrm{PC}$ & $\mathrm{H} 1$ & 88.31 & 85.59 & 9.23 & 0.93 & $0.53-0.01$ & 61.87 & 0.21 & 0.99 \\
\hline $\mathrm{PC}_{\mathrm{DCB}}$ & \multicolumn{8}{|c|}{ Lead } & 0.98 \\
\hline LB & $\mathrm{L} 2$ & 32.03 & 33.57 & 2.33 & 0.99 & $0.82-0.04$ & 19.04 & 0.31 & 0.94 \\
\hline $\mathrm{LB}_{\mathrm{DCB}}$ & L1 & 41.81 & 41.92 & 2.36 & 0.98 & $0.82-0.04$ & 23.36 & 0.29 & 0.97 \\
\hline $\mathrm{PC}$ & $\mathrm{HC}$ & 273.79 & 523.04 & 3.26 & 0.97 & $0.76-0.03$ & 486.85 & 0.56 & 0.99 \\
\hline $\mathrm{PC}_{\mathrm{DCB}}$ & \multicolumn{8}{|c|}{ Zinc } & 1.00 \\
\hline LB & L1 & 7.87 & 8.42 & 0.92 & 0.99 & $0.92-0.10$ & 3.47 & 0.40 & 0.94 \\
\hline $\mathrm{LB}_{\mathrm{DCB}}$ & L1 & 6.01 & 6.71 & 0.79 & 0.87 & $0.93-0.12$ & 2.98 & 0.30 & 0.97 \\
\hline $\mathrm{PC}$ & $\mathrm{H} 2$ & 13.42 & 13.60 & 7.47 & 0.81 & $0.04-0.0004$ & 10.09 & 0.14 & 0.96 \\
\hline $\mathrm{PC}_{\mathrm{DCB}}$ & $\mathrm{H} 2$ & 7.75 & 8.07 & 2.63 & 0.75 & $0.06-0.0006$ & 5.46 & 0.12 & 0.95 \\
\hline
\end{tabular}

$\mathrm{Cu}$, and $\mathrm{Zn}$ in both samples. Differences in the sorbed concentrations found before and after the extraction were lower for $\mathrm{Cd}$ and $\mathrm{Zn}$ than for $\mathrm{Pb}$ and $\mathrm{Cu}$.

\subsection{Metal sorption on the soil mineral particles before and after the Fe-oxyhydroxide removal}

The TEM-EDS analyses were primarily focused on the mineralogy and chemical composition of the clay mineral particles, Fe-oxyhydroxide particles, and their associations. In the sample PC, calcite particles were also analyzed. Figure 3 presents a summary of the analyzed metal concentrations on the studied particle types.

Metal concentrations found on the particles decreased in the following order: $\mathrm{Cu}>\mathrm{Pb}>\mathrm{Zn}>\mathrm{Cd}$. This sorption sequence was observed on each particle type of both samples before and after the DCB extraction (Table 3). However, differences among the sorbed metal concentrations were not significant for certain particle types. In the sample LB, the sorption of $\mathrm{Cu}$ and $\mathrm{Pb}$ was significantly higher than that of $\mathrm{Zn}$ and $\mathrm{Cd}$, except on smectites, where only the sorption of $\mathrm{Cu}$ was significantly higher than that of $\mathrm{Zn}$ and $\mathrm{Cd}$. Additionally, the
$\mathrm{Cu}$ sorption was significantly higher than that of $\mathrm{Pb}$ on the illite-smectite particles before and after the DCB extraction. In the sample $\mathrm{PC}, \mathrm{Cu}$ and $\mathrm{Pb}$ sorption were significantly higher than $\mathrm{Zn}$ and $\mathrm{Cd}$ sorption on each particle type. Copper sorption was also significantly higher than $\mathrm{Pb}$ sorption on the illite/ smectite and smectite particles before and after the DCB extraction and on the clay-ferrihydrite associations before the extraction.

The sorbed metal concentrations by the soil particles were generally higher in the sample PC than in the sample LB. However, this difference was not significant for $\mathrm{Cd}$ and $\mathrm{Zn}$ on the illite/smectite and smectite particles and $\mathrm{Zn}$ in the clayferrihydrite associations. Generally, no significant change in metal concentrations was found after the DCB extraction. However, the concentration of $\mathrm{Pb}$ increased significantly on illite/smectite and smectite, as well as on calcite and smectite particles after the extraction in the sample LB and PC, respectively. Additionally, in the sample PC, Cd sorption decreased on calcite and clayferrihydrite particles, and $\mathrm{Zn}$ sorption decreased on calcite and illite/smectite particles after the extraction.

In both samples, sorbed metal concentrations showed no significant differences among the studied particle types 

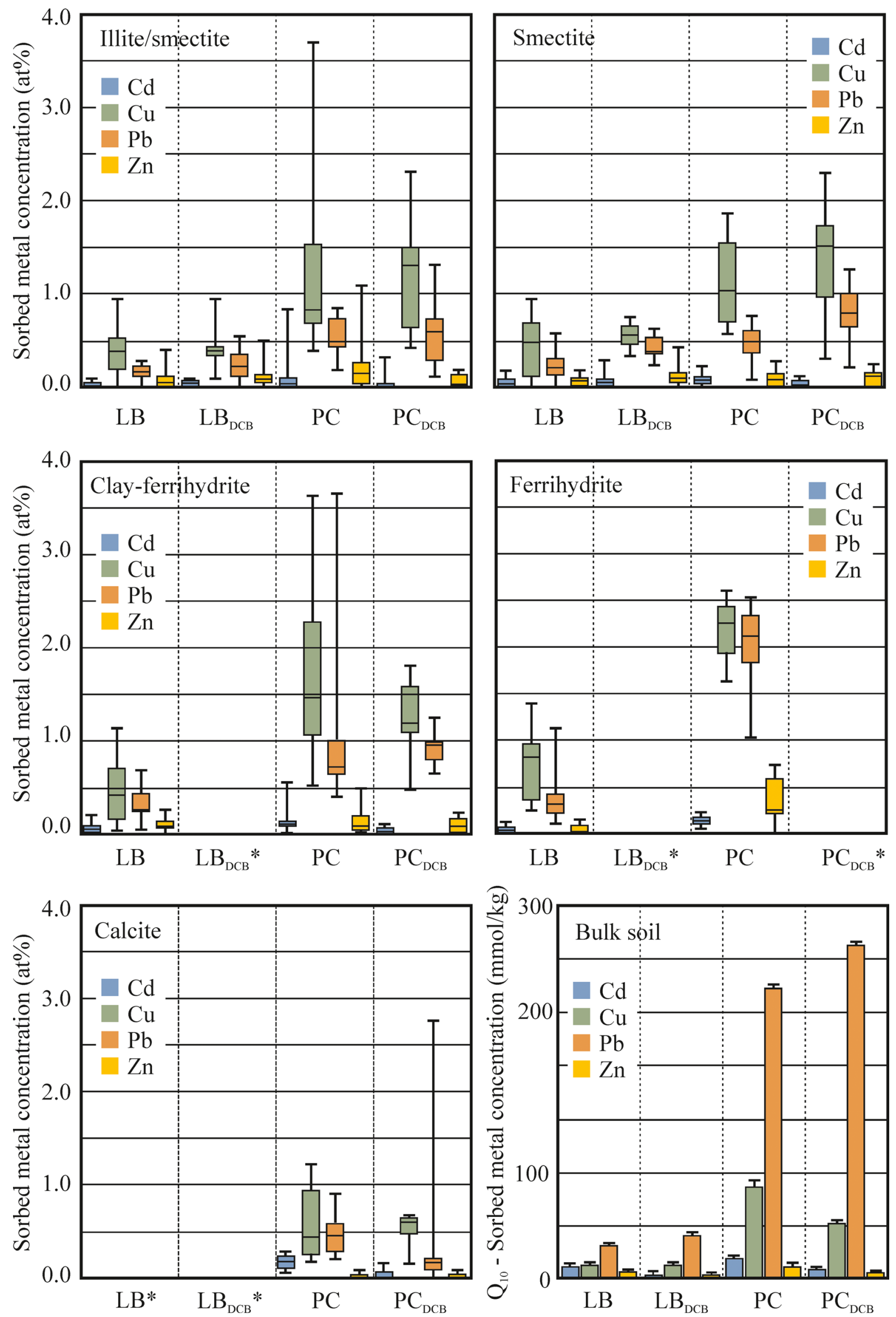
Fig. 3 Sorbed metal concentrations on the studied particle types and the bulk soils. Between 14 and 42 particles was studied by point chemical analysis (TEM-EDS) within the studied particle type groups. DCB refers to the results after the DCB extraction. *Note that no sufficient number of clay-ferrihydrite and/or ferrihydrite particles remained after the DCB extraction for data evaluation, and sample LB did not contain calcite

(Table 4). In the sample LB, the lowest metal sorption was found for illite/smectite particles, except for $\mathrm{Zn}$, where ferrihydrite particles sorbed the lowest concentrations. Smectite particles sorbed higher metal concentrations than the highest $\mathrm{Cd}$ and $\mathrm{Zn}$ sorption for clay-ferrihydrite associations. In the sample PC, the highest metal concentrations were sorbed by the ferrihydrite particles for each metal. Clay-ferrihydrite associations sorbed slightly lower metal concentrations than the ferrihydrite particles. Illite/smectite particles sorbed slightly higher metal concentrations than smectite particles before the DCB extraction, and its opposite was found after the extraction. Calcite particles generally sorbed the lowest metal concentrations.

Correlation coefficients between the major chemical components and the sorbed metal concentrations of the studied particles were calculated. In the sample LB (Table 5), strong positive correlations $(r>0.50)$ were found between $\mathrm{Fe}$ and $\mathrm{Cd}$ in the illite/smectite particles; between $\mathrm{Al}$ and $\mathrm{Zn}$, between $\mathrm{Fe}$ and $\mathrm{Cu}, \mathrm{Pb}, \mathrm{Zn}$, between $\mathrm{Ca}$ and $\mathrm{Pb}$, and between $\mathrm{K}$ and $\mathrm{Pb}$ in the smectite particles. Strong negative correlations $(r<-0.50)$ were found between $\mathrm{Fe}$ and $\mathrm{Pb}$ in the ferrihydrite particles. In the sample PC (Table 6), a strong positive correlation was found between $\mathrm{Si}$ and $\mathrm{Cd}, \mathrm{Cu}, \mathrm{Pb}$, between $\mathrm{Al}$ and $\mathrm{Cd}, \mathrm{Cu}$, and between $\mathrm{Fe}$ and $\mathrm{Cd}, \mathrm{Cu}, \mathrm{Pb}$ in the calcite particles; between $\mathrm{Fe}$ and $\mathrm{Pb}$, between $\mathrm{Mg}$ and $\mathrm{Cu}, \mathrm{Pb}$, and between $\mathrm{Ca}$ and $\mathrm{Pb}$ in the illite/smectite particles; between $\mathrm{Al}$ and $\mathrm{Cu}$, and between $\mathrm{K}$ and $\mathrm{Cu}$ in the smectite particles; finally between $\mathrm{Fe}$ and $\mathrm{Cu}$ in the clay-ferrihydrite particles. Strong negative correlations $(r<-0.50)$ were found between $\mathrm{Mg}$ and $\mathrm{Zn}$, and between $\mathrm{Ca}$ and $\mathrm{Cd}, \mathrm{Cu}, \mathrm{Pb}$ in the calcite particles; between $\mathrm{Na}$ and $\mathrm{Pb}$, and between $\mathrm{K}$ and $\mathrm{Zn}$ in the smectite particles; finally between $\mathrm{Si}$ and $\mathrm{Cd}, \mathrm{Cu}, \mathrm{Pb}$, and $\mathrm{Zn}$ in the clayferrihydrite associations.

\section{Discussion}

\subsection{Ferrihydrite removal}

Our mineralogical analyses revealed that both soils contained the mineral particles and their associations being in focus. Although the prevalence of the illite/smectite and smectite particles differs in the studied soils, both samples provided these particle types together with those of ferrihydrite in large numbers enough for comparison. The ferrihydrite removal was efficient in both samples, although the alkaline soil still contained a low number after the extraction. Several studies showed that the use of DCB does not guarantee the complete extraction of Fe-oxyhydroxides (Rennert 2019), which could be related to its protection by soil organic matter (Eusterhues et al. 2014) or by amorphous silicates (Filimonova et al. 2016). In our case, the high frequency of turbostratic smectites and the presence of amorphous silica particles may have resulted in such prevention in the alkaline soil, despite the optimal soil $\mathrm{pH}$ for dithionite reduction (Pansu and Gautheyrou 2006). On the other hand, the structural Fe of smectite particles were not extracted using the DCB extraction, which was required to study its role in metal sorption.

The removal of ferrihydrite resulted in changes in the shape of the sorption curves of certain metals. According to Zhou et al. (2020), this may reflect the difference between the surface sorption sites' types and affinities before and after the extraction. The ferrihydrite removal also increased the $\mathrm{Pb}$ sorption and decreased that of other metals in the bulk soils. Higher $\mathrm{Pb}$ concentrations were also observed on the clay
Table 3 Sequences of sorbed metal concentrations on the bulk soils and particle types. The difference is not significant when the greater-than sign is put within parentheses. The sequences for the bulk soils are based on the $Q_{10}$ values. Note that no sufficient number of clay-ferrihydrite and/or ferrihydrite particles remained after the DCB extraction for data evaluation

\begin{tabular}{lll}
\hline & Sample $\mathrm{LB}$ & Sample $\mathrm{LB}_{\mathrm{DCB}}$ \\
\hline Bulk soil & $\mathrm{Pb}>\mathrm{Cu}(>) \mathrm{Cd}>\mathrm{Zn}$ & $\mathrm{Pb}>\mathrm{Cu}>\mathrm{Zn}>\mathrm{Cd}$ \\
Illite/smectite & $\mathrm{Cu}>\mathrm{Pb}>\mathrm{Zn}(>) \mathrm{Cd}$ & $\mathrm{Cu}>\mathrm{Pb}>\mathrm{Zn}>\mathrm{Cd}$ \\
Smectite & $\mathrm{Cu}(>) \mathrm{Pb}(>) \mathrm{Zn}(>) \mathrm{Cd}$, but $\mathrm{Cu}>\mathrm{Zn}, \mathrm{Cd}$ & $\mathrm{Cu}(>) \mathrm{Pb}>\mathrm{Zn}(>) \mathrm{Cd}$ \\
Clay-ferrihydrite & $\mathrm{Cu}(>) \mathrm{Pb}>\mathrm{Zn}(>) \mathrm{Cd}$ & - \\
Ferrihydrite & $\mathrm{Cu}(>) \mathrm{Pb}>\mathrm{Zn}=\mathrm{Cd}$ & - \\
& $\mathrm{Sample} \mathrm{PC}$ & $\mathrm{Sample} \mathrm{PC}_{\mathrm{DCB}}$ \\
Bulk soil & $\mathrm{Pb}>\mathrm{Cu}>\mathrm{Cd}>\mathrm{Zn}$ & $\mathrm{Pb}>\mathrm{Cu}>\mathrm{Cd}>\mathrm{Zn}$ \\
Calcite & $\mathrm{Cu}(>) \mathrm{Pb}>\mathrm{Cd}(>) \mathrm{Zn}$ & $\mathrm{Cu}(>) \mathrm{Pb}>\mathrm{Cd}(>) \mathrm{Zn}$ \\
Illite/smectite & $\mathrm{Cu}>\mathrm{Pb}>\mathrm{Zn}(>) \mathrm{Cd}$ & $\mathrm{Cu}>\mathrm{Pb}>\mathrm{Zn}(>) \mathrm{Cd}$ \\
Smectite & $\mathrm{Cu}>\mathrm{Pb}>\mathrm{Zn}(>) \mathrm{Cd}$ & $\mathrm{Cu}>\mathrm{Pb}>\mathrm{Zn}(>) \mathrm{Cd}$ \\
Clay-ferrihydrite & $\mathrm{Cu}>\mathrm{Pb}>\mathrm{Zn}(>) \mathrm{Cd}$ & $\mathrm{Cu}(>) \mathrm{Pb}>\mathrm{Zn}(>) \mathrm{Cd}$ \\
Ferrihydrite & $\mathrm{Cu}(>) \mathrm{Pb}>\mathrm{Cd}(>) \mathrm{Zn}$ & - \\
\hline
\end{tabular}


Table 4 Sequences of the sorption capacities of the studied particle types in the samples before and after the DCB extraction. The difference is not significant when the greater-than sign was put within parentheses. $C$ calcite, $I S$ illite/smectite, $S$ smectite, $C F$ clay-ferrihydrite association, $F$ ferrihydrite. Note that no sufficient number of clayferrihydrite and/or ferrihydrite particles remained after the DCB extraction for data evaluation, and sample LB did not contain calcite

\begin{tabular}{|c|c|c|}
\hline & Sample LB & Sample $\mathrm{LB}_{\mathrm{DCB}}$ \\
\hline $\mathrm{Cd}$ & $\mathrm{CF}(>) \mathrm{S}(>) \mathrm{F}(>) \mathrm{IS}$ & S (>) IS \\
\hline $\mathrm{Cu}$ & $\mathrm{F}(>) \mathrm{S}(>) \mathrm{CF}(>) \mathrm{IS}$ & S (>) IS \\
\hline $\mathrm{Pb}$ & $\mathrm{F}(>) \mathrm{CF}(>) \mathrm{S}(>) \mathrm{IS}$, but $\mathrm{F}>\mathrm{IS}$ & $\mathrm{S}>\mathrm{IS}$ \\
\hline \multirow[t]{2}{*}{$\mathrm{Zn}$} & $\mathrm{CF}=\mathrm{IS}(>) \mathrm{S}(>) \mathrm{F}$ & S (>) IS \\
\hline & Sample PC & Sample $\mathrm{PC}_{\mathrm{DCB}}$ \\
\hline $\mathrm{Cd}$ & $\mathrm{F}(>) \mathrm{CF}(>) \mathrm{IS}(>) \mathrm{S}>\mathrm{C}$, but $\mathrm{F}>\mathrm{S}$ & $\mathrm{IS}(>) \mathrm{CF}=\mathrm{S}(>) \mathrm{C}$ \\
\hline $\mathrm{Cu}$ & $\mathrm{F}(>) \mathrm{CF}(>) \mathrm{IS}(>) \mathrm{S}(>) \mathrm{C}$, but F $>\mathrm{S}, \mathrm{C} ; \mathrm{CF}>\mathrm{C}$ & $\mathrm{S}(>) \mathrm{CF}(>) \mathrm{IS}>\mathrm{C}$ \\
\hline $\mathrm{Pb}$ & $\mathrm{F}>\mathrm{CF}>\mathrm{IS}(>) \mathrm{C}(>) \mathrm{S}$ & $\mathrm{CF}(>) \mathrm{S}(>) \mathrm{IS}>\mathrm{C}$ \\
\hline $\mathrm{Zn}$ & $\mathrm{F}(>) \mathrm{IS}(>) \mathrm{CF}(>) \mathrm{C}(>) \mathrm{S}$ & $\mathrm{S}(>) \mathrm{CF}(>) \mathrm{IS}(>) \mathrm{C}$, but $\mathrm{S}>\mathrm{C}$ \\
\hline
\end{tabular}

mineral particles after the extraction, but no significant change was found for the other metals in this case. Removal of coatings through $\mathrm{Fe}$-oxyhydroxide extraction may reduce cation accessibility to ferrihydrite surface and expose additional metal sorption sites, like interlayer space of clay minerals ( $\mathrm{Wu}$ et al. 1999). As ferrihydrite possesses a positive surface charge in acidic soils, it can neutralize the negative surface charge of clay minerals as coatings ( $\mathrm{Li}$ et al. 2015). Thus, its removal reduces the repulsion between the metal cations and the coated surfaces, which is expected to increase the metal cations' sorption (Elliot et al. 1988). However, at alkaline soil conditions, the negatively charged ferrihydrite surface also attracts metal cations (Silveira et al. 2002). Our results suggest that the ferrihydrite coatings present on the surface of clay particles blocked the sorption of $\mathrm{Pb}$ in both soils. That is why $\mathrm{Pb}$ sorption increased both on smectite and illite/smectite particles after the extraction. Model calculations also showed that $\mathrm{Pb}$ exhibits a higher affinity than $\mathrm{Cu}, \mathrm{Cd}$, and $\mathrm{Zn}$ for the different surface sites of illite (Gu and Evans 2007) and montmorillonite ( $\mathrm{Gu}$ et al. 2010) at a wide $\mathrm{pH}$ range. Contrary to $\mathrm{Pb}$, sorption of $\mathrm{Cd}, \mathrm{Cu}$, and $\mathrm{Zn}$ did not change on the clay particles after removing coatings, but their lower sorption in the bulk soils suggests the primary role of ferrihydrite in their sorption. According to Cavallaro and McBride (1984), metals' sorption is reduced only at $\mathrm{pH}$ values below the onset of hydrolysis of metals after the Fe-oxyhydroxide removal. This $\mathrm{pH}$-value is 6.1-7.2 for $\mathrm{Pb}, 6.9-8.1$ for $\mathrm{Cu}, 7.8-8.6$ for $\mathrm{Zn}$, and 9.4-10.1 for Cd (Takeno 2005). Thus, hydrolysis of $\mathrm{Zn}$ and $\mathrm{Cd}$ is not probable in our case, and it is just partly likely for $\mathrm{Cu}$ in the alkaline soil, as equilibrium $\mathrm{pH}$ values are far below the soil $\mathrm{pH}$ because of adsorption. For $\mathrm{Pb}$, however, hydrolysis may occur in the alkaline soil supporting its preferred sorption even after ferrihydrite removal.

\subsection{Sorption sequences}

The higher metal sorption in the alkaline than in the acidic soil was found in the bulk soil and mineral particles. However, the shape of the sorption curves and the calculated sorption isotherm parameters all suggested high affinity (Giles and Smith 1974) and favorable sorption (Worch 2012), respectively, in each case. The $\mathrm{pH}$ controls the surface charge properties of soil components, the solubility, and hydrolysis of metals directly leading to preferred sorption for cationic elements at
Table 5 Correlation matrix of Pearson correlation coefficients for the concentrations of major chemical components and sorbed metals of the studied particle types in the sample LB. Correlation coefficients showing high correlation $(-050>r>0.50)$ are highlighted with italics. Between
14 and 32 particles was studied by point chemical analysis (TEM-EDS) within the studied particle type groups. *Although the correlation coefficient suggested a strong relationship, it was influenced by a few outlier data

\begin{tabular}{|c|c|c|c|c|c|c|c|c|c|c|c|c|c|c|c|c|}
\hline & \multicolumn{4}{|c|}{ Illite/smectite } & \multicolumn{4}{|c|}{ Smectite } & \multicolumn{4}{|c|}{ Clay-ferrihydrite } & \multicolumn{4}{|c|}{ Ferrihydrite } \\
\hline & $\mathrm{Cd}$ & $\mathrm{Cu}$ & $\mathrm{Pb}$ & $\mathrm{Zn}$ & $\mathrm{Cd}$ & $\mathrm{Cu}$ & $\mathrm{Pb}$ & $\mathrm{Zn}$ & $\mathrm{Cd}$ & $\mathrm{Cu}$ & $\mathrm{Pb}$ & $\mathrm{Zn}$ & $\mathrm{Cd}$ & $\mathrm{Cu}$ & $\mathrm{Pb}$ & $\mathrm{Zn}$ \\
\hline $\mathrm{Si}$ & $-0.50^{*}$ & 0.45 & -0.04 & 0.11 & -0.31 & -0.35 & -0.43 & $-0.51 *$ & -0.27 & -0.10 & -0.34 & -0.02 & -0.20 & 0.27 & -0.33 & 0.13 \\
\hline $\mathrm{Al}$ & -0.26 & -0.10 & 0.15 & 0.30 & 0.21 & 0.17 & 0.22 & 0.61 & 0.07 & -0.30 & -0.27 & -0.02 & 0.00 & 0.08 & 0.03 & -0.24 \\
\hline $\mathrm{Fe}$ & 0.50 & -0.29 & 0.03 & 0.05 & $0.53 *$ & 0.58 & 0.68 & 0.62 & 0.34 & 0.32 & 0.35 & 0.00 & -0.02 & 0.13 & -0.56 & 0.34 \\
\hline $\mathrm{Mg}$ & 0.22 & -0.32 & -0.21 & 0.02 & 0.33 & 0.46 & 0.49 & 0.49 & -0.03 & -0.31 & -0.02 & 0.02 & 0.18 & -0.38 & -0.48 & 0.17 \\
\hline $\mathrm{Ca}$ & 0.18 & -0.28 & $-0.51 *$ & 0.18 & 0.20 & 0.40 & 0.75 & 0.11 & 0.19 & 0.00 & -0.07 & 0.11 & $0.58^{*}$ & -0.40 & -0.14 & $0.62 *$ \\
\hline $\mathrm{Na}$ & 0.06 & -0.41 & 0.30 & -0.19 & 0.02 & 0.03 & 0.32 & -0.40 & -0.24 & -0.14 & 0.03 & 0.08 & -0.12 & 0.14 & 0.01 & 0.11 \\
\hline K & 0.37 & 0.35 & 0.11 & -0.20 & 0.28 & 0.46 & 0.54 & 0.41 & -0.14 & -0.41 & -0.17 & 0.03 & -0.03 & 0.02 & 0.07 & -0.42 \\
\hline
\end{tabular}




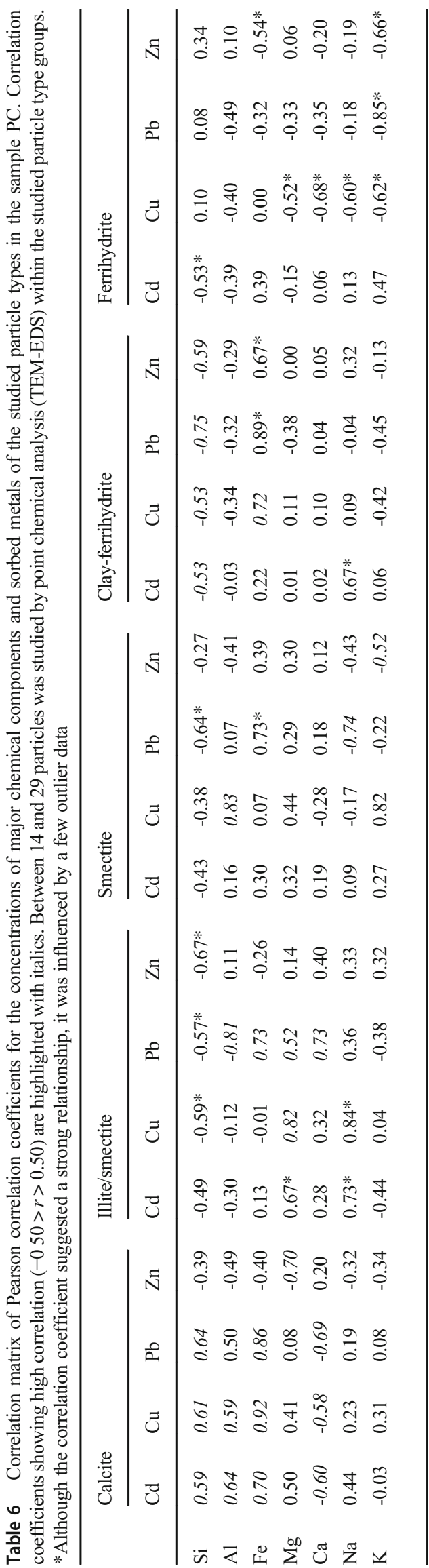

alkaline conditions (Young 2013). Saturation was not achieved in each case, suggesting further available surface sites and/or precipitation for the metals. Based on the shape of the sorption curves, precipitation could be supposed for $\mathrm{Pb}$ in the alkaline soil. The higher metal sorption could be related to the higher $\mathrm{pH}$ of the alkaline soil unambiguously, and the high calcite content of this sample favors the precipitation of certain metals. Our earlier data supported the formation of (hydro)cerussite during the sorption experiments in the studied alkaline soil (Sipos et al. 2018; Sipos et al. 2019). Significant differences among the sorbed metal concentrations on the two soils' mineral particles were only found for $\mathrm{Cu}$ and $\mathrm{Pb}$. Contrarily, the lack of such differences suggests that the effect of competition was higher than that of soil $\mathrm{pH}$ on the sorption of $\mathrm{Cd}$ and $\mathrm{Zn}$ by the mineral particles. It is well-known that more strongly sorbing elements (like $\mathrm{Pb}$ and $\mathrm{Cu}$ ) are less affected by competition than more mobile elements (like $\mathrm{Cd}$ and $\mathrm{Zn}$ ) (Basta and Tabatabai 1992; Usman 2008). Significant differences among the soil mineral particles' sorbed metal concentrations were rather characteristic of the alkaline soil. The lower the $\mathrm{pH}$, the higher the effect of competition on the sorption of metals, and it is more expressed for those characterized by lower sorption, as shown by Mesquita et al. (2002).

The sorption sequences showed differences between the bulk soils and mineral particles. The higher sorption of $\mathrm{Pb}$ and $\mathrm{Cu}$ than that of $\mathrm{Cd}$ and $\mathrm{Zn}$ is a well-known phenomenon in soils and their components. This behavior is generally related to metal properties like ionic radius, hydrated radius, electronegativity, hydrolysis constant, and Misono softness value. The dominance of the exact sorption process (e.g., ion exchange, surface complexation, or precipitation) within a given soil will specify which of the above parameters can be more related to the preferential sorption of given metal(s) (Shaheen et al. 2013). Several studies (e.g., Seo et al. 2008; Usman 2008) found similar sorption sequences to those found in this study. They related the high sorption of metals to their low first hydrolysis constant and their high softness values. However, our direct analysis of the particles showed that mineral surfaces' role is higher in the sorption of $\mathrm{Cu}$ than for $\mathrm{Pb}$. It is higher in $\mathrm{Cd}$ sorption than in $\mathrm{Zn}$ sorption, despite their lower bulk sorption, respectively. The sorption sequence observed on the soil mineral particles follows the decreasing electronegativity of metals, which can be related to the metals' decreasing ability to dissociate $\mathrm{H}$ from the surface functional groups of soil particles and form covalent bonding (Gomes et al. 2001). However, sorption on organic matter and precipitation must have also affected the metals' behavior as competing processes, which is primarily apparent for $\mathrm{Pb}$. As mentioned above, precipitation is predominantly characteristic of $\mathrm{Pb}$ in the alkaline soil. Precipitation can be related to the calcite's presence in this sample, which often results in the formation of alkalinity-derived insoluble 
species (Orucoglu et al. 2018). Based on our solubility calculations in Sipos et al. (2018), $\mathrm{Pb}$ precipitation in the form of (hydroxy)carbonate preceded other metals. For $\mathrm{Cu}$ (and to a smaller extent for $\mathrm{Cd}$ ), however, sorption by soil organic matter may have also contributed to its higher sorption in the alkaline sample. Several studies found that soil organic matter can affect $\mathrm{Cu}$ retention only when its amount is higher than a threshold (Yang et al. 2014; Antoniadis and Golia 2015). In our case, the low TOC content of the samples supported a low amount of organic surface sites for the high load of metals, so their contribution to the metal sorption could be primarily expected for the one with the highest affinity towards the organic surfaces. Consequently, sorption by organic compounds could be more characteristic of $\mathrm{Pb}$ in the acidic soil.

\subsection{Sorption on mineral particles}

The highest sorbed $\mathrm{Cu}$ and $\mathrm{Pb}$ concentrations were found on ferrihydrite particles, followed by the clay-ferrihydrite associations. Moreover, the lower the silicates' ratio, the higher the sorbed metal concentration in the clay-ferrihydrite associations in the alkaline soil. These all show ferrihydrite's primary role in $\mathrm{Cu}$ and $\mathrm{Pb}$ sorption, although the ferrihydrite's surface charge properties are expected to be different in the two soils. Although ferrihydrite has a negative surface charge only at alkaline conditions, it can be an effective sorbent for metals, even in acidic soils. This characteristic is because of its low crystallinity resulting in not evenly distributed charge properties (Sahraoui et al. 2015). Interestingly, the sorbed $\mathrm{Pb}$ concentrations decreased with the increasing $\mathrm{Fe}$ content of the ferrihydrite particles in the acidic soil, and its reverse was found for $\mathrm{Cu}$ in the alkaline soil. Although ferrihydrite exhibits highly varying chemical and mineralogical characteristics in soils (Vodyanitskii and Shoba 2016), its Fe content may be closely related to its crystallinity (Das et al. 2011). Our TEM analyses, however, showed similar characteristics for ferrihydrite in both samples concerning their crystallinity. Consequently, variation in the particles' $\mathrm{Fe}$ content can be more due to the trace amounts of other phases (primarily silicates). The surface charge properties of ferrihydrite prefer the cationic metal sorption at alkaline conditions over the acidic one, as supported by these data.

Differences between the sorption behavior of $\mathrm{Cu}$ and $\mathrm{Pb}$ were rather conspicuous on the clay particles. Copper sorption on clay surfaces was preferred over $\mathrm{Pb}$ in both soils irrespective of the presence or absence of ferrihydrite coatings. As stated above, the removal of coatings resulted in the increase of $\mathrm{Pb}$ sorption on clay surfaces, which is in agreement with the results of model calculations showing the high competing ability of $\mathrm{Pb}$. However, this metal prefers the sorption on $\mathrm{Fe}$ oxyhydroxides and organic surfaces over $\mathrm{Cu}$ even in mineral soils, as shown by the calculations of Vidal et al. (2008). Higher metal sorption was found for smectite in the acidic soil than for illite/smectite particles, as expected. This difference was the case only after the removal of Fe-oxyhydroxides in the alkaline sample. These data suggest that the effect of ferrihydrite coatings prevailed for smectite particles, primarily in the alkaline soil. Besides the surface charge compensation and blocking of interlayer space, the interaction of ferrihydrite and smectite may also result in the loss of swelling properties through the formation of Fe-rich smectite and/or chamosite (Mizutani et al. 1991). Blocking of access and changing of swelling properties are probable also at alkaline conditions, where also higher metal sorption is expected due to favorable metal (hydrolysis properties) and surface (increase of negatively charged sites) properties (Jalali and Moharrami 2007). Thus, the lower effect of coatings in the acidic soil can be probably related to the unfavorable metal sorption due to lower $\mathrm{pH}$ and higher competition than the alkaline soil.

Metal sorption on the clay particles could be related to the $\mathrm{Fe}$ concentration of the clays in the acidic soil, and this was only found for $\mathrm{Pb}$ in the alkaline soil. Additionally, $\mathrm{Pb}$ sorption on clay particles increased with the increasing concentrations of certain base cations in both soils, and this was the case also for $\mathrm{Cu}$ in the alkaline soil. Saha et al. (2002) found that each metal was preferentially bound to different surface sites in hydroxyl-aluminum and montmorillonite complexes. Gustaffson et al. (2011) observed similar behavior of metals on ferrihydrite. Thus, the different behavior of metals (primarily that of $\mathrm{Cu}$ and $\mathrm{Pb}$ ) in our case does not necessarily indicate that their preferred sorption sites overlap in soils at different $\mathrm{pH}$ values. According to $\mathrm{Wu}$ et al. (2009), Femontmorillonite shows higher interlayer spacing and higher affinity for metals than its parent Ca-variant at a wide $\mathrm{pH}$ range. Kypritidou and Argyraki (2018) suggest a combination of sorption mechanisms during the interaction of Fe-rich smectite and metals, which involves the synergetic effect of ion exchange, surface complexation, and precipitation mechanisms. In the acidic soil, ion exchange was expected to prevail for each metal, but it took place characteristically at different surface sites (or particle) for different metals. However, in the alkaline soil, surface complexation's role increased primarily for $\mathrm{Pb}$ based on its lower hydrolysis constant. Moreover, precipitation of $\mathrm{Pb}$ on the surface of clay particles was also probable in this case. Interestingly, precipitation of metals on the surface of calcite particles was not observed in our case. The decrease of metal sorption indicates a lack of precipitation on calcite particles after the ferrihydrite removal and the increasing concentration of metals with $\mathrm{Si}, \mathrm{Al}$, and $\mathrm{Fe}$ on calcite. In agreement with the results of Sdiri and Higashi (2012), clay and Fe-oxyhydroxide coatings promote the sorption of metals on limestone. Precipitation also explains the large difference between the bulk sorption of $\mathrm{Pb}$ and that of $\mathrm{Cd}$ and $\mathrm{Zn}$. In contrast, no difference was found between their sorbed concentrations on the clay particles. Cadmium and $\mathrm{Zn}$ sorption characteristics on the soil mineral particles could not 
be related unambiguously to differences in soil $\mathrm{pH}$ or the presence of Fe-oxyhydroxides. Likewise, these metals' sorbed concentration can be less related to the particles' major chemical components, and if such a relationship exists, they can be hardly explained. These metals also exhibited lower sorption than $\mathrm{Cu}$ and $\mathrm{Pb}$ in the bulk soils, and the effect of the competition is stronger than that of $\mathrm{pH}$ or mineral surfaces in their case. They probably sorbed rather by ion exchange processes on the mineral particles in both soils, which were strongly inhibited by the competing metals. However, their ion exchange with base cations on the clay particles could not be demonstrated directly by TEM-EDS analyses.

\section{Conclusions}

Noticeable differences among soil particles' sorption capacity could be observed for metals with higher sorption and soil conditions preferring metals' sorption. The role of mineral surfaces is higher in $\mathrm{Cu}$ sorption than in that of $\mathrm{Pb}$, and it is higher in $\mathrm{Cd}$ sorption than in that of $\mathrm{Zn}$, despite their lower bulk sorption, respectively. Their higher sorption could be related to their higher ability to form covalent bonding. The higher sorption of $\mathrm{Cu}$ than that of $\mathrm{Pb}$ was the most conspicuous on the clay particles, although their sorption took place at different surface sites and through various processes probably. The effect of competition on $\mathrm{Cd}$ and $\mathrm{Zn}$ sorption was generally stronger than that of $\mathrm{pH}$ or mineral surfaces.

The Fe-oxyhydroxide removal discontinued the accessibility of $\mathrm{Cd}, \mathrm{Cu}$, and $\mathrm{Zn}$ for ferrihydrite, thereby resulting in a decrease of their bulk sorption. Contrarily, $\mathrm{Pb}$ was able to sorb on clay particles' exposed sites after removing ferrihydrite coatings due to its favorable competing ability. The effect of ferrihydrite coatings on metal sorption prevails at smectite particles and primarily in the alkaline soil. Its limited impact in the acidic soil can be probably related to the unfavorable metal sorption due to low $\mathrm{pH}$ and high competition.

Our results also support the observations about the soil system's heterogeneity and even that of its individual components. This soil characteristic makes the evaluation of the role of soil components in metal sorption more difficult. The combination of different approaches seems to be promising; however, further systematic works are required to get a more indepth insight into the soil-metal interaction.

Supplementary Information The online version contains supplementary material available at https://doi.org/10.1007/s11368-021-02899-x.

Acknowledgements This study was financially supported by the National Research Development and Innovation Office (project No. K1050099) and by the Hungarian Academy of Sciences (NANOMIN project, KEP-8/2018). Adrienn Tóth and Viktória Kovács Kis thank for the support of the János Bolyai Research Scholarship of the Hungarian
Academy of Sciences. Viktória Kovács Kis is indebted to the ÚNKP-19-4 New National Excellence Program of the Ministry for Innovation and Technology. The electron microscopy facility at Centre for Energy Research was granted by the European Structural and Investment Funds (grant No. VEKOP-2.3.3-15-2016-00002).

Funding Open access funding provided by ELKH Research Centre for Astronomy and Earth Sciences.

Open Access This article is licensed under a Creative Commons Attribution 4.0 International License, which permits use, sharing, adaptation, distribution and reproduction in any medium or format, as long as you give appropriate credit to the original author(s) and the source, provide a link to the Creative Commons licence, and indicate if changes were made. The images or other third party material in this article are included in the article's Creative Commons licence, unless indicated otherwise in a credit line to the material. If material is not included in the article's Creative Commons licence and your intended use is not permitted by statutory regulation or exceeds the permitted use, you will need to obtain permission directly from the copyright holder. To view a copy of this licence, visit http://creativecommons.org/licenses/by/4.0/.

\section{References}

Agbenin JO, Olojo LA (2004) Competitive adsorption of copper and zinc by a $\mathrm{B}_{\mathrm{t}}$ horizon of a savanna Alfisol as affected by $\mathrm{pH}$ and selective removal of hydrous oxides and organic matter. Geoderma 119:8589. https://doi.org/10.1016/S0016-7061(03)00242-8

Antoniadis V, Golia EE (2015) Sorption of $\mathrm{Cu}$ and $\mathrm{Zn}$ in low organic matter-soils as influenced by soil properties and by degree of soil weathering. Chemosphere 138:364-369. https://doi.org/10.1016/j. chemosphere.2015.06.037

Basta NT, Tabatabai MA (1992) Effect of cropping systems on adsorption of metals by soils III. Competitive adsorption. Soil Sci 153: 331-337

Borgnino L, Avena MJ, De Pauli CP (2009) Synthesis and characterization of $\mathrm{Fe}$ (III)-montmorillonites for phosphate adsorption. Colloid Surface A 341:46-52. https://doi.org/10.1016/j.colsurfa.2009.03. 037

Cavallaro N, McBride MB (1984) Zinc and copper sorption and fixation by an acid soil clay: Effect of selective dissolutions. Soil Sci Soc Am J 48:1050-1054. https://doi.org/10.2136/sssaj1984. $03615995004800050020 \mathrm{x}$

Cerqueira B, Arenas-Lago D, Andrade ML, Vega FA (2015) Using time of flight secondary ion mass spectrometry and field emission scanning electron microscopy with energy dispersive X-ray spectroscopy to determine the role of soil components in competitive copper and cadmium migration and fixation in soils. Geoderma 251-252: 65-77. https://doi.org/10.1016/j.geoderma.2015.03.026

Covelo EF, Matías JM, Vega FA, Reigosa MJ, Andrade ML (2008) A tree regression analysis of factors determining the sorption and retention of heavy metals by soil. Geoderma 147:75-85 j.geoderma.2008.08.001

Das S, Hendry MJ, Essilfie-Dughan J (2011) Transformation of two-line ferrihydrite to goethite and hematite as a function of $\mathrm{pH}$ and temperature. Environ Sci Technol 45:268-275. https://doi.org/10.1021/ es101903y

Elliot HA, Liberati MR, Huang CP (1988) Effect of iron oxide removal on heavy metal sorption by acidic subsoils. Water Air Soil Pollut 27: 379-389. https://doi.org/10.1007/BF00649419

Eusterhues K, Hädrich A, Neidhardt J, Küsel K, Keller TF, Jandt KD, Totsche KU (2014) Reduction of ferrihydrite with adsorbed and 
coprecipitated organic matter: microbial reduction by Geobacter bremensis vs. abiotic reduction by Na-dithionite. Biogeosciences 11:4953-5966. https://doi.org/10.5194/bg-11-4953-2014

Filimonova S, Kaufhold S, Wagner FE, Häusler W, Kögel-Knaber I (2016) The role of allophane nano-structure and Fe oxide speciation for hosting soil organic matter in an allophanic Andosol. Geochim Cosmochim Acta 180:284-302. https://doi.org/10.1016/j.gca.2016. 02.033

Giles CH, Smith D (1974) A general treatment and classification of the solute adsorption isotherm I. Theoretical. J Colloid Interface Sci 47: 755-765. https://doi.org/10.1016/0021-9797(74)90252-5

Gomes PC, Fontes MPF, da Silva AG, de S Mendoca E, Netto AR (2001) Selectivity sequence and competitive adsorption of heavy metals by Brazilian soils. Soil Sci Soc Am J 65:1115-1121. https://doi.org/10. 2136/sssaj2001.6541115x

Gomez-Gonzalez MA, Villalobos M, Marco JF, Garcia-Guinea J, Bolea E, Laborda F, Garrido F (2018) Iron oxide - clay composite vectors on long-distance transport of arsenic and toxic metals in miningaffected areas. Chemosphere 197:759-767. https://doi.org/10.1016/ j.chemosphere.2018.01.100

Gu X, Evans LJ (2007) Modelling the adsorption of Cd(II), Cu(II), Ni(II), $\mathrm{Pb}(\mathrm{II})$, and $\mathrm{Zn}$ (II) onto Fithian illite. J Colloid Interface Sci 307:317325. https://doi.org/10.1016/j.jcis.2006.11.022

Gu X, Evans LJ, Barabash SJ (2010) Modeling the adsorption of Cd (II), $\mathrm{Cu}$ (II), $\mathrm{Ni}$ (II), $\mathrm{Pb}$ (II) and $\mathrm{Zn}$ (II) onto montmorillonite. Geochim Cosmochim Acta 74:5718-5728. https://doi.org/10.1016/j.gca. 2010.07.016

Gustaffson JP, Tiberg C, Edkymish A, Kleja DB (2011) Modelling lead(II) sorption to ferrihydrite and soil organic matter. Environ Chem 8:485-492. https://doi.org/10.1071/EN11025

Harris W, White NG (2008) X-ray diffraction techniques for soil mineral identification. In: Ulrey AL, Dress R (eds) Methods of Soil Analysis, Part 5, Mineralogical Methods, SSSA Book Series, No. 5. Soil Science Society of America, Madison, pp 81-116

Jackson ML, Lim CH, Zelazny LW (1986) Oxides, hydroxides, and aluminosilicates. In: Klute A (ed) Methods of soil analysis, Part 1, Agronomy Monograph 9. American Society of Agronomy and Soil Science Society of America, Madison, pp 101-150

Jalali M, Moharrami S (2007) Competitive adsorption of trace elements in calcareous soils of western Iran. Geoderma 140:156-163. https:// doi.org/10.1016/j.geoderma.2007.03.016

Kopittke PM, Wang P, Lombi E, Donner E (2017) Synchrotron-based Xray approaches for examining toxic trace metal (loid) $\mathrm{s}$ in soil-plant systems. J Environ Qual 46:1175-1189. https://doi.org/10.2134/ jeq2016.09.0361

Kypritidou Z, Argyraki A (2018) A multi-site mechanism model for studying $\mathrm{Pb}$ and $\mathrm{Cu}$ retention from aqueous solutions by $\mathrm{Fe}-\mathrm{Mg}$ rich clays. Clay Miner 53:175-192. https://doi.org/10.1180/clm. 2018.12

Li Z, Huang B, Huang J, Chen G, Zhang C, Nie X, Luo N, Yao H, Ma W, Zeng G (2015) Influence of removal of organic matter and iron and manganese oxides on cadmium adsorption by red paddy soil aggregates. RSC Adv 5:90588-90595. https://doi.org/10.1039/ c5ra16501f

Malandrino M, Abollino O, Giacomino A, Aceto M, Mentasti E (2006) Adsorption of heavy metals on vermiculite: Influence of $\mathrm{pH}$ and organic ligands. J Colloid Interface Sci 299:537-546. https://doi. org/10.1016/j.jcis.2006.03.011

Mesquita ME, Carranca C, Manino MR (2002) Influence of $\mathrm{pH}$ on copper-zinc competitive adsorption by a sandy soil. Environ Technol 23:1043-1050.https://doi.org/10.1080/ 09593332308618352

Mikutta R, Kleber M, Torn MS, Jahn R (2006) Stabilization of soil organic matter: association with minerals or chemical recalcitrance? Biogeochemistry 77:25-56. https://doi.org/10.1007/s10533-0050712-6
Mizutani T, Fukushima Y, Okada A, Kamigaito O, Kobayashi T (1991) Synthesis of 1: 1 and 2: 1 iron phyllosilicates and characterization of their iron state by Mössbauer spectroscopy. Clay Clay Miner 39: 381-386. https://doi.org/10.1346/CCMN.1991.0390407

Orucoglu E, Tournassat C, Robinet JC, Madé B, Lundy M (2018) From experimental variability to the sorption related retention parameters necessary for performance assessment models for nuclear waste disposal systems: the example of $\mathrm{Pb}$ adsorption on clay minerals. Appl Clay Sci 163:20-32. https://doi.org/10.1016/j.clay.2018.07. 003

Pansu M, Gautheyrou J (2006) Handbook of soil analysis. Springer, Berlin. https://doi.org/10.1007/978-3-540-31211-6

Refaey Y, Jansen B, El-Shater AH, El-Haddad AA, Kalbitz K (2014) The role of dissolved organic matter in adsorbing heavy metals in clayrich soils. Vadose Zone J 13:1-12. https://doi.org/10.2136/vzj2014. 01.0009

Rafaey Y, Jansen B, Parsons JR, de Voogt P, Bagnis S, Markus A, ElShater A-H, El-Haddad A-A, Kalbitz K (2017) Effects of clay minerals, hydroxides, and timing of dissolved organic matter addition on the competitive sorption of copper, nickel, and zinc: A column experiment. J Environ Manag 187:273-285. https://doi.org/10.1016/j. jenvman.2016.11.056

Rennert T (2019) Wet-chemical extractions to characterise pedogenic Al and Fe species - a critical review. Soil Res 57:1-16. https://doi.org/ $10.1071 / \mathrm{sr} 18299$

Saha UK, Taniguchi S, Sakurai K (2002) Simultaneous adsorption of cadmium, zinc, and lead on hydroxyaluminum- and hydroxyaluminosilicate-montmorillonite complexes. Soil Sci Soc Am J 66:117-128. https://doi.org/10.2136/sssaj2002.1170

Sahraoui H, Andrade ML, Covelo EF, Hachicha H, Tarhouni J, Oliveira LFS, Vega FA (2015) Sorption and desorption of $\mathrm{Pb} 2+$ and $\mathrm{Cu} 2+$ in different Tunisian soils. Fresenius Environ Bull 24:1909-1919

Sdiri A, Higashi T (2012) Simultaneous removal of heavy metals from aqueous solution by natural limestones. Appl Water Sci 3:29-39. https://doi.org/10.1007/s13201-012-0054-1

Seo DC, Yu K, DeLaune RD (2008) Comparison of monometal and multimetal adsorption in Mississippi River alluvial wetland sediment: Batch and column experiments. Chemosphere 73:17571764. https://doi.org/10.1016/j.chemosphere.2008.09.003

Shaheen SM, Tsalidas CD, Rinklebe J (2013) A review of the distribution coefficients of trace elements in soils: Influence of sorption system, element characteristics, and soil colloidal properties. Adv Colloid Interf Sci 201-202:43-56. https://doi.org/10.1016/j.cis.2013.10.005

Shang C, Zelazny LW (2008) Selective dissolution techniques for mineral analysis of soils and sediments. In: Ulery AL, Drees LR (eds) Methods of soil analysis, Part 5, Mineralogical methods, SSSA Book Series, No. 5. Soils Science Society of America, Madison, pp 33-80

Silveira MLA, Alleoni LRF, Camargo OA, Casagrande JC (2002) Copper adsorption in oxidic soils after removal of organic matter and iron oxides. Commun Soil Sci Plant Anal 33:3581-3592. https://doi.org/10.1081/CSS-120015907

Sipos P, Németh T, Kovács Kis V, Mohai I (2009) Association of individual soil mineral constituents and heavy metals as studied by sorption experiments and analytical electron microscopy analyses. J Hazard Mater 168:1512-1520. https://doi.org/10.1016/j.jhazmat. 2009.03.033

Sipos P, Kovács Kis V, Balázs R, Tóth A, Kovács I, Németh T (2018) Contribution of individual pure or mixed-phase mineral particles to metal sorption in soils. Geoderma 324:1-8. https://doi.org/10.1016/ j.geoderma.2018.03.008

Sipos P, Tóth A, Kovács Kis V, Balázs R, Kovács I, Németh T (2019) Partition of $\mathrm{Cd}, \mathrm{Cu}, \mathrm{Pb}$ and $\mathrm{Zn}$ among mineral particles during their sorption in soils. J Soils Sediments 19:1775-1787. https://doi.org/ $10.1007 / \mathrm{s} 11368-018-2184-\mathrm{z}$ 
Swift RS (1996) Organic matter characterization. In: Sparks DL (ed) Methods of soil analysis: Chemical methods, Part 3. Soil Science Society of America, Madison, pp 1011-1069. https://doi.org/10. 2136/sssabookser5.3.c35

Takeno N (2005) Atlas of Eh-pH diagrams. Geological Survey of Japan Open File Report No. 419.

Tran HN, You S-J, Hosseini-Bandegharaei A, Chao H-P (2017) Mistakes and inconsistencies regarding adsorption of contaminants from aqueous solutions: A critical review. Water Res 120:88-116. https://doi.org/10.1016/j.watres.2017.04.014

Usman ARA (2008) The relative adsorption selectivities of $\mathrm{Pb}, \mathrm{Cu}, \mathrm{Zn}$, $\mathrm{Cd}$ and $\mathrm{Ni}$ by soils developed on shale in New Valley, Egypt. Geoderma 144:334-343. https://doi.org/10.1016/j.geoderma.2007. 12.004

Uygur V, Rimmer DL (2000) Reactions of zinc with iron-oxide coated calcite surfaces at alkaline pH. Eur J Soil Sci 51:511-516. https:// doi.org/10.1046/j.1365-2389.2000.00318.x

Van Groeningen N, Thomas-Arrigo LK, Byrne JM, Kappler A, Christl I, Kretschmar R (2020) Interactions of ferrous iron with clay mineral surfaces during sorption and subsequent oxidation. Environ Sci Process Impacts 22:1355-1367. https://doi.org/10.1039/ D0EM00063A

Vidal M, Santos MF, Abrão T, Rodríguez J, Rigol A (2008) Modeling competitive metal sorption in a mineral soil. Geoderma 149:189198. https://doi.org/10.1016/j.geoderma.2008.11.040

Violante A, Pigna M (2002) Competitive sorption of arsenate and phosphate on different clay minerals and soils. Soil Sci Soc Am J 66: 1788-1796. https://doi.org/10.2136/sssaj2002.1788

Vodyanitskii YN, Shoba SA (2016) Ferrihydrite in soils. Euras Soil Sci 49:796-806. https://doi.org/10.1134/S1064229316070127

Worch E (2012) Adsorption technology in water treatment: Fundamentals, processes, and modeling. De Gruyter, Berlin. https://doi.org/10.1515/9783110240238

Wu J, Laird DA, Thompson ML (1999) Sorption and desorption of copper on soil clay components. J Environ Qual 28:334-338. https:// doi.org/10.2134/jeq1999.00472425002800010041x

Wu P, Wu W, Li S, Xing N, Zhu N, Li P, Wu J, Yang C, Dang Z (2009) Removal of $\mathrm{Cd}^{2+}$ from aqueous solution by adsorption using $\mathrm{Fe}-$ montmorillonite. J Hazard Mater 169:824-830. https://doi.org/10. 1016/j.jhazmat.2009.04.022

Wu X, Wei Y, Wang J, Wang D, She L, Wang J, Cai C (2017) Effects of soil physicochemical properties on aggregate stability along a weathering gradient. Catena 156:205-215. https://doi.org/10.1016/ j.catena.2017.04.017

$\mathrm{Xu}$ Y, Axe L (2005) Synthesis and characterization of iron oxide-coated silica and its effect on metal adsorption. J Colloid Interface Sci 282: 11-19. https://doi.org/10.1016/j.jcis.2004.08.057

Yang J, Liu J, Dynes JJ, Peak D, Regier T, Wang J, Zhu S, Shi J, Tse JS (2014) Speciation and distribution of copper in a mining soil using multiple synchrotron-based bulk and microscopic techniques. Environ Sci Pollut Res 21:2943-2954. https://doi.org/10.1007/ s11356-013-2214-8

Young SD (2013) Chemistry of heavy metals and metalloids in soils. In: Alloway BJ (ed) Heavy Metals in Soils: Trace Metals and Metalloids in Soils and their Bioavailability. Springer Dordrecht, Berlin, pp 51-95. https://doi.org/10.1007/978-94-007-4470-7_3

Zachara JM, Smith SC, Resch CT, Cowan CE (1992) Cadmium sorption to soil separates containing layer silicates and iron and aluminum oxides. Soil Sci Soc Am J 56:1074-1084. https://doi.org/10.2136/ sssaj1992.03615995005600040012x

Zachara JM, Gassman PL, Smith SC, Taylor D (1995) Oxidation and adsorption of Co(II)EDTA ${ }^{2-}$ complexes in subsurface materials with iron and manganese oxide grain coatings. Geochim Cosmochim Acta 59:4449-4463. https://doi.org/10.1016/0016-7037(95)99265-I

Zhao Z, Nie T, Yang Z, Zhou W (2018) The role of soil components in the sorption of tetracycline and heavy metals in soils. RSC Adv 8: 32178-32187. https://doi.org/10.1039/C8RA06631K

Zhou Y, Sherpa S, McBride MB (2020) Pb and Cd chemisorption by acid mineral soils with variable $\mathrm{Mn}$ and organic matter contents. Geoderma 368:114274. https://doi.org/10.1016/j.geoderma.2020. 114274

Publisher's note Springer Nature remains neutral with regard to jurisdictional claims in published maps and institutional affiliations. 